\title{
Analyze the Challenges and Problems in Air Cargo Operations, Chennai, Tamil Nadu
}

\author{
S. Vasantha \\ Professor, School of Management Studies, \\ Vels Institute of Science, Technology \& Advanced Studies (VISTAS), Chennai, Tamil Nadu, India \\ E-Mail: vasantha.sms@ velsuniv.ac.in
}

\begin{abstract}
The paper aims at understanding the problems of air cargo operations. The study is about identifying the problems during the import and export of the cargo through air transport. There are different stages of the process involved in the import and export of cargo. Some of the major processes are Export operations, Import Operations, AWB (Airway Bill) management, Freight Forwarding, Customs clearance, Transportation. This study gives an idea about problems and challenges in air cargo operations. The problems like a procedural bottleneck of customs clearance, Congestion at airport cargo terminal, Reducing dwell time, unskilled manpower, Inefficient use of belly cargoes capacity, Forecasting Airline cargo capacity and space allocation, challenges of handling hazardous cargo and dangerous cargo etc. For various problems, an overview of the relevant literature review is presented. The data are collected from various employees through questionnaire and observation method which is the primary data collection method used in the research. The data is analyzed by applying statistical tool, suggestion and conclusion are given purely based on the values obtained from the analysis and Interpretation.
\end{abstract}

Keywords: Challenges, Problems, Air Cargo Operations

\section{INTRODUCTION}

Air cargo occupies an important role in international trade and economic growth of the country. Air cargo is the movement or transportation of cargo like high value and perishable cargo from a place of origin to destination in any part of the globe. The major key players are Airlines, Air cargo terminal operators, ground handling service provider, forwarders, Domestic cargo transport service provider and Custom House Agents. The industry presents a variety of service providers with the same goal and minded purpose of "moving the goods faster and efficient delivery". From the point of view of the airline industry, Air cargo service contributes near about $20 \%$ of their revenue. India's international Air trade to GDP ratio has doubled from $4 \%$ to $8 \%$ in the last twenty years.

Air cargo is an integral part of the day to day, involves shipment of highly time sensitive, temperature controlled and high-value goods. This could be perishables products, pharmaceutical items, live animals, electronics etc. that need an efficient end-to-end supply chain. In order to ensure the effective smooth flow of air cargo is to enhance the safety, improving the security, strengthening the value proposition of air cargo, driving efficiency through global standards, improving the quality and building sustainability.
In Air cargo movement, cargo handling operations are the preparation of cargo shipments, loading, and unloading of the cargo in aircraft and transfer of cargo between storage facilities and land transportation. For outbound cargo, the preparation includes consolidation of cargo, building up of the air cargo pallets and containers, inspection and documentation. For inbound cargo, the preparation includes customs and other regulatory procedures, as well as deconsolidation.

\section{A. India's Economic Performance}

The rate, pattern and structure of the growth of the Indian economy have significant implications for the Air Cargo logistics Business in India as these are highly interconnected.

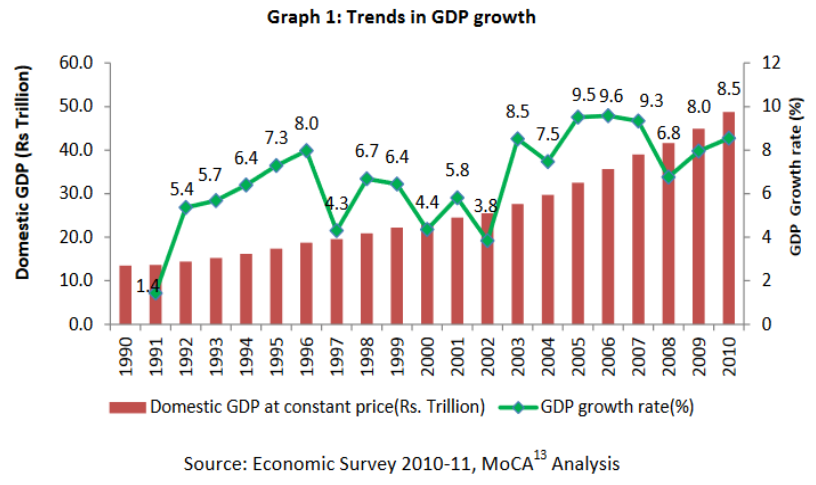

Fig. 1 Trends in GDP Growth

TABLE I INDIA's MERCHANDISE TRADE-GDP RATIO IN THE PERIOD 1990-90 To 2010-11

\begin{tabular}{|c|c|}
\hline Year & India's Merchandise Trade-GDP Ratio \\
\hline $1990-91$ & $14.2 \%$ \\
\hline $2000-01$ & $21.9 \%$ \\
\hline $2004-05$ & $29.5 \%$ \\
\hline $2010-11$ & $37.8 \%$ \\
\hline \multicolumn{2}{|c|}{ Source: RBI, MoCA Analysis }
\end{tabular}

The merchandise Trade to GDP ratio indicates the level of integration with the global economy. From Table $\mathrm{I}$ it is evident that India's merchandise Trade to GDP ratio increased from $14.2 \%$ in $1990-91$ to $37.8 \%$ in $2010-11$. The trade to GDP ratio peaked in the year 2008-09 to $42 \%$. 


\section{LITERATURE REVIEW}

Report of Working Group on Air Cargo Logistics (2012), reported that air cargo logistics as a key element of the Civil Aviation sector. For the next 20 years, air cargo throughput is projected to grow by 8 to 10 times as present level. It necessitatesthe development of infrastructure facilities, simplifying customs procedure, adoption of advanced information technology, automation, and development of human resource are needed for the growth of this sector. The two most main players in an air cargo supply chain are the airlines and the forwarders. A big challenge that airlines face is demand estimation and capacity planning. The successful approach to increase capacity estimate is to make forwarders share their demand information (Hihara, 2014)

As per industry estimates, the volume of air cargo traffic in the country will be around 2.64 million tonnes during the year 2017. Delhi International Airport is considered as the India's second largest airport in terms of cargo traffic, with air cargo traffic growing in the country, global air freight majors are line up to get a share of the earnings. But to support the growth of air cargo in the country, airport infrastructure needs to expand, with more reserved cargo terminals

Airlines generally experience the issue that the total of freight forwarders' orders surpasses the airline's fixed capacity for hot-selling routes, while the orders are usually $<50$ percent for underutilized routes. Airlines cannot actively change flights to report the imbalance, since they have to attend passenger traffic when carrying cargo in the belly space of passenger flights. (Feng, Bo \& Li, Yanzhi \& Shen, Huaxiao. 2015).

Arvind Nayak, Managing Director, Nayak Aviation Sevices Pvt Ltd (2016) highlighted that E-Commerce has changed the dynamics of domestic air cargo and we can see not only growth but also induction of skilled manpower and technology into the industry. Murphy et al., (1989) found that $35 \%$ of airports and air cargo companies interviewed perceived the administrative documentation as the major problem at airports. Moreover, the inefficiency of customs can form a source of delay at the airport and airports that provide reliable, timely customs clearance or even preclearance can build up a competitive advantage. World customs organization stated that the challenge for the customs administration is keeping the balance between the effectiveness and efficiency for cargo inspection of the express cargo airlines because it requires quick and faster clearance. International Civil Aviation Organization (ICAO) and International Air Transport Association (IATA) (2017) reported, that shipping the dangerous and hazardous material from point of origin to destination are handled in strict adherence to transport regulations to save you from liability. For transporting these kinds of goods, have to ensure, specially trained staff are to be employed.Daniel et.al said the purpose of packaging goods for transportation is to protect them from possible damage, allow for proper handling, and obtain an efficient space usage inside the transport unit while permitting the stability of the transport vehicle.

\section{OBJECTIVES OF THE STUDY}

1. To analyze the Challenges and problems in Air cargo operations.

2. To identify various problems in cargo packaging and handling.

3. To analyze the reason for a spell over (cargo delay) cargo in airlines.

4. To identify various challenges in handling Dangerous and Hazardous cargo.

\section{METHODOLOGY}

Descriptive Research Design is adopted to study the challenges of air cargo operations.Both primary and secondary data collection method has been followed. Primary data was collected through a structured questionnaire survey. The sample selected for the study consists of 40 respondents. The respondents are chosen based on purposive nonprobability sampling technique. The respondents of the study are employees who are working in air cargo operations.

\section{ANALYSIS AND INTERPRETATION}

\section{A. Demographic Profile of Respondents}

TABLE I DEMOGRAPHIC PROFILE OF RESPONDENTS

\begin{tabular}{|c|c|c|c|c|}
\hline $\begin{array}{l}\text { S. } \\
\text { No. }\end{array}$ & Demographic & Description & Frequency & Percentage \\
\hline \multirow{2}{*}{1} & \multirow{2}{*}{ Gender } & Male & 26 & 65 \\
\hline & & Female & 14 & 35 \\
\hline \multirow{4}{*}{2} & \multirow{4}{*}{ Age } & Below 30 & 11 & 27.5 \\
\hline & & Below 40 & 11 & 27.5 \\
\hline & & Below 50 & 17 & 42.5 \\
\hline & & $\begin{array}{l}50 \text { and } \\
\text { Above }\end{array}$ & 1 & 2.5 \\
\hline \multirow{3}{*}{3} & \multirow{3}{*}{ Experience } & $0-3$ years & 7 & 17.5 \\
\hline & & 3-6 years & 11 & 27.5 \\
\hline & & $\begin{array}{l}\text { Above } 6 \\
\text { years }\end{array}$ & 22 & 55 \\
\hline
\end{tabular}

The above table shows the personal profile of the respondents gender wise distribution show that 65 percentage of the respondent are Male, 35 percentage of the respondent are Female. Age wise classification of the data shows that 43 percentage of respondent are below 50 years, 28 percentage of below 40 years, 28 percentage of below 30 years and 3 percentage of them are 50 years and above. Experience classification shows that 55 percentage of respondents are experienced more than 6 years, 28 percentage of respondents are experienced 3 to 6 years. 
TABle II CHALLENGES In AIR CARGo OPERATIONS

\begin{tabular}{|l|c|c|}
\hline \multicolumn{1}{|c|}{$\begin{array}{c}\text { Challenges In Air Cargo } \\
\text { operations }\end{array}$} & Mean & $\begin{array}{c}\text { Std. } \\
\text { Deviation }\end{array}$ \\
\hline Lack of Skilled Manpower & 3.95 & 0.846 \\
\hline Inadequate use of Technology & 3.75 & 1.104 \\
\hline $\begin{array}{l}\text { Lack of dedicated terminal space } \\
\text { and facilities for express Airlines }\end{array}$ & 3.48 & 1.261 \\
\hline $\begin{array}{l}\text { Delay in documentation and Custom } \\
\text { Procedure }\end{array}$ & 3.08 & 1.474 \\
\hline $\begin{array}{l}\text { Lack of Efficiency level of Badhra } \\
\text { (Ground Handling Agent) }\end{array}$ & 3.40 & 1.336 \\
\hline
\end{tabular}

The data presents the results of the employee's perception towards the Challenges in air cargo operations. The above table shows the item mean score and standard deviation. Based on the mean score "Lack of Skilled Manpower" (3.95) is the main problem experienced by the respondents, followed by Inadequate use of Technology (3.75), Lack of dedicated terminal space and facilities for express Airlines (3.48), Lack of efficiency level of Badhra (Ground handling Agent) (3.40), Delay in documentation and Custom procedure (3.08). The experience of the respondents in dealing with the air cargo service is important to determine the level of effectiveness of air cargo movement.

TABle III Customs Clearance And Documentation

\begin{tabular}{|l|c|c|}
\hline \multicolumn{1}{|c|}{$\begin{array}{c}\text { Customs Clearance And } \\
\text { Documentation }\end{array}$} & Mean & $\begin{array}{c}\text { Std. } \\
\text { Deviation }\end{array}$ \\
\hline 24*7 Services are not available & 3.83 & 1.394 \\
\hline Clearance process done manually & 3.20 & 1.114 \\
\hline Documents are not digitalized & 3.63 & 1.030 \\
\hline Shortage of Manpower (Officers) & 3.88 & 1.067 \\
\hline $\begin{array}{l}\text { Proper Officers not available at all } \\
\text { Time }\end{array}$ & 3.05 & 1.319 \\
\hline $\begin{array}{l}\text { Customers are not Presenting } \\
\text { Proper Documents at right time }\end{array}$ & 3.43 & 1.217 \\
\hline $\begin{array}{l}\text { Single Window system is not } \\
\text { effective }\end{array}$ & 3.53 & 1.109 \\
\hline
\end{tabular}

The table shows the mean score and standard deviation for the problem experienced by the respondents in Air cargo Customs procedure and documentation. Based on the mean score "Shortage of manpower (Officers)" (3.88) is the highest challenge faced by the respondents WCO (1999) stated that Maintaining the balance between effectiveness and efficiency for cargo inspection, particularly for express cargoes that demand high efficiency, is a challenge for the Customs Administration.

Murphy et al., (1989) found that 35\% of airports and air cargo companies interviewed perceived the administrative documentation as the major problem at airports. Moreover, the inefficiency of customs can form a source of delay at the airport and airports that provide reliable, timely customs clearance or even pre-clearance can build up a competitive advantage.
TABLE Iv CARGO PACKAGING AND HANDLING

\begin{tabular}{|l|c|c|}
\hline \multicolumn{1}{|c|}{ Packaging And Handling } & Mean & $\begin{array}{c}\text { Std. } \\
\text { Deviation }\end{array}$ \\
\hline $\begin{array}{l}\text { Improper Cargo Packaging leads to } \\
\text { Damage }\end{array}$ & 3.78 & 1.310 \\
\hline Pilferage & 3.68 & 1.289 \\
\hline $\begin{array}{l}\text { Material Can't be reused } \\
\text { (manufacturing goods) }\end{array}$ & 3.35 & 0.975 \\
\hline $\begin{array}{l}\text { Carelessness of Manpower leads to } \\
\text { damage }\end{array}$ & 4.10 & 0.591 \\
\hline Improper Handling leads to Damage & 3.43 & 1.259 \\
\hline \multicolumn{2}{|c|}{ (Source: Primary data) }
\end{tabular}

The table shows the mean score and standard deviation for the problems in air cargo packaging and handling experienced by the employees. Based on the mean score "Carelessness of Manpower leads to damage" (4.10) is the main challenge experienced by the employees, followed by Improper cargo Packaging leads to Damage (3.78),Pilferage (3.68),Improper Packaging (3.43), Material can't be reused (manufacturing goods) (3.35).

TABle V Truck Lay Bay AND SPILl Over CARgo

\begin{tabular}{|l|c|c|}
\hline \multicolumn{1}{|c|}{ Truck Lay \& Spill Over } & Mean & $\begin{array}{c}\text { Std. } \\
\text { Deviation }\end{array}$ \\
\hline $\begin{array}{l}\text { Increase in Passenger baggage movement, } \\
\text { cargo gets delayed (Spill Over) }\end{array}$ & 3.88 & 1.067 \\
\hline $\begin{array}{l}\text { By loading spill over cargo, exact cargo to } \\
\text { load in airline gets damaged }\end{array}$ & 3.40 & 1.008 \\
\hline Cargo Customers Dissatisfaction & 3.35 & 1.252 \\
\hline Lack of Parking Space & 3.63 & 0.979 \\
\hline System Procedural Delay & 3.63 & 0.925 \\
\hline $\begin{array}{l}\text { Airlines giving proper carting Order to the } \\
\text { Trucks }\end{array}$ & 3.83 & 1.107 \\
\hline
\end{tabular}

The table shows the mean score for the problem in "truck lay bay", the trucks to be parked in airport and "spillover cargo" in the airlines, experienced by the employees. Based on the mean score "Increase in Passenger baggage movement, cargo gets delayed (Spill Over)" (3.88) is the top strategy that is experienced by the employees, followed by Airlines giving proper carting order to the Trucks (3.83), Lack of Parking Space (3.63), System Procedural delay (3.63), By loading spill over cargo, exact cargo to load in airline gets damaged (3.40), cargo Customers dissatisfaction (3.35).The Result indicates that each and every variable denotes that Truck lay bay and spill over cargo.

TABLe Vi HaZardous AND Dangerous Goods

\begin{tabular}{|l|c|c|}
\hline \multicolumn{1}{|c|}{ Hazardous and Dangerous } & Mean & $\begin{array}{c}\text { Std. } \\
\text { Deviation }\end{array}$ \\
\hline $\begin{array}{l}\text { Acceptable for transport on both Passenger } \\
\text { and Cargo aircraft }\end{array}$ & 3.55 & 1.280 \\
\hline Higher Officers Approval is done easily & 3.13 & 1.343 \\
\hline DG Qualified manpower scares & 3.45 & 0.932 \\
\hline Unskilled manpower in handling Dg goods & 3.30 & 1.091 \\
\hline Mis-declared dangerous goods & 3.43 & 1.174 \\
\hline
\end{tabular}


The table shows the mean score for the challenges and problems in handling Hazardous and Dangerous cargo in air shipments, experienced by the employees. Based on the mean score "Acceptable for transport on both passenger and cargo aircraft" (3.55) is the top strategy that is experienced by the employees, followed by DG Qualified manpower scares (3.45), Mis-declared dangerous goods (3.43), Unskilled manpower in handling Dg goods (3.30), Higher Officers Approval is done easily (3.13). The result indicates that each variabledenote that handling of dangerous and hazardous cargo should be done with special care.

The table shows the mean score for the problems with the Infrastructure in Chennai Airport, experienced by the respondents. Based on the mean score "Cargo Congestion in Airport" (3.73) is the top strategy that is experienced by the employees, followed by Airport is capable of handling future demand cargo (3.70), equipments are utilized properly (3.53), Adoptable of New technology systems (3.45), Skilled manpower are handling the cargo (3.33).

TABLE VII INFRASTRUCTURE AT AIRPORT

\begin{tabular}{|l|c|c|}
\hline \multicolumn{1}{|c|}{ Infrastructure } & Mean & $\begin{array}{c}\text { Std. } \\
\text { Deviation }\end{array}$ \\
\hline $\begin{array}{l}\text { Airport is capable of handling future } \\
\text { demand cargo }\end{array}$ & 3.70 & 1.265 \\
\hline $\begin{array}{l}\text { Skilled manpower is handling the cargo } \\
\text { (I2) }\end{array}$ & 3.33 & 0.917 \\
\hline Cargo Congestion in Airport & 3.73 & 0.960 \\
\hline Equipment's are utilized properly & 3.53 & 1.154 \\
\hline Adoptable of New technology systems & 3.45 & 1.339 \\
\hline
\end{tabular}

The result indicates that lack of Infrastructure in Chennai Airport which leads to decrease in Customer service.

Table ViII Pearson Correlation Coefficient Between Various Challenges In Air Cargo Operations

\begin{tabular}{|c|c|c|c|c|c|c|}
\hline Correlation & $\begin{array}{c}\text { Challenges } \\
\text { In } \\
\text { Air Cargo } \\
\text { Operations }\end{array}$ & $\begin{array}{c}\text { Customs } \\
\text { Clearance } \\
\& \\
\text { Documentation }\end{array}$ & $\begin{array}{c}\text { Packaging } \\
\text { \& } \\
\text { Handling }\end{array}$ & $\begin{array}{c}\text { Truck Lay } \\
\text { Bay \& Spill } \\
\text { Over }\end{array}$ & $\begin{array}{c}\text { Hazardous and } \\
\text { Dangerous } \\
\text { Cargo }\end{array}$ & Infrastructure \\
\hline $\begin{array}{l}\text { Challenges In Air Cargo } \\
\text { Operations }\end{array}$ & 1 & -.071 & .293 & $.463^{* *}$ & .000 & -.036 \\
\hline $\begin{array}{l}\text { Customs Clearance \& } \\
\text { Documentation }\end{array}$ & & 1 & .263 & $.450^{* *}$ & $.512^{* * *}$ & $.396^{*}$ \\
\hline Packaging \& Handling & & & 1 & $.412^{* *}$ & .293 & -.004 \\
\hline $\begin{array}{l}\text { Truck Lay Bay \& Spill } \\
\text { Over }\end{array}$ & & & & 1 & $.470^{* *}$ & .032 \\
\hline $\begin{array}{l}\text { Hazardous and } \\
\text { Dangerous Cargo }\end{array}$ & & & & & 1 & $.483^{* *}$ \\
\hline Infrastructure & & & & & & 1 \\
\hline
\end{tabular}

The above table describes correlation coefficient between challenges in air cargo operations. From the above table it is clear that the correlation between Customs Clearance \& Documentation and Hazardous and Dangerous Cargo is high when compare to other factors which is showing 51.2 percent.

\section{DISCUSSIONS}

The results of employee's perception towards the Challenges in air cargo shows, that "lack of skilled manpower are identified as major challenges in air cargo operations" (Mean 3.95) is the main challenge face that is experienced by the respondents.It was found that the major problem in customs clearance and documentation is "Shortage of proper officers at right time (working hours)" (Mean 3.88) is the top challenges that are delivered by the respondents.

It is observed from the study that the cargo packaging and handling are affects the operations and service, in that "Carelessness of manpower leads damage" (Mean 4.10).
The result seems that improper and unskilled manpower affect the handling of cargo which leads to damage. According to Dangerous Goods regulations (both federal and provincial), while handling transportation of dangerous cargo via road "safety mark", must be used which can be a combination of "design, symbol, device, sign, label, placard, letter, word, number, abbreviation.

It was found that the major problem in truck lay bay is "Airlines are not giving carting order to the trucks, at right time" (Mean 3.83) is the main challenges faced by the respondents.

Based on the analysis, spill over cargo in air shipments mostly happens because of "Increase in passenger baggage movement, cargo gets delayed" (Mean 3.88).The problems occur may unfortunate but it affects the cargo movement when it comes to combination aircraft. It is observed from the study that the movement of dangerous and hazardous cargo is affected because of "Not Acceptable for transport on both passenger and cargo aircraft" (Mean 3.55). The result seems that Airlines are not ready to accept these kinds 
of goods along with a passenger.On analyzing the results of respondent's perception towards the infrastructure in the airport affect the movement and service of operations. Based on the mean score "cargo congestion" (Mean 3.73) is the top category that is experienced by the respondents. Tsekeris (2011) stated that the privatization initiative of the 1990's was to ensure an unceasing rise in efficiency levels for the airport infrastructure and in turn boost regional development. One of the most common concerns in the developing world is the long dwell time for air cargo. To improve efficiency, Cargo handlers at air cargo terminals should ensure efficient timely and secure handling of the cargo.

\section{CONCLUSION}

India is developing as one of the fastest growing air cargo markets across the globe and presents ample opportunities for industry operators. India is also considered as key aviation market and its potential for growth is strengthened by policy reforms of the Indian government like privatization of airports and foreign investment in airport infrastructure all over the placeof the country. It primarily measures and compares the challenges and problems faced in the air cargo industry with reference to Chennai airport. The challenges are addressing several challenges such as infrastructure, handling, and packaging of cargo, challenges in handling hazardous and dangerous cargo and customs clearance and documentation. Thus the study has made to identify those problems and to provide the relevant suggestions. All the Customs procedures can be done at the Airport warehouse and cargo can be taken to the airport by the carriers as per priority to avoid the congestion and delay in the process.

\section{REFERENCES}

[1] Baxter, G., Srisaeng, P., Wild, G. (2018). The role of the airbus A380-800 aircraft in a full-service network airline's commercial operations and route network design: the case of Thai airways international. Aeron Aero Open Access J., 2(4), 223-236.

[2] Daniel Hellström, Annika Olsson \& Fredrik Nilsson, (2016). Designing packaging, Managing Packaging Design for Sustainable Development, 35-61.

[3] Feng, Bo \& Li, Yanzhi \& Shen, Huaxiao. (2015). Tying mechanism for airlines' air cargo capacity allocation. European Journal of Operational Research. 244. 10.1016/j.ejor.2015.01.014.

[4] Hihara, K., 2014. An analysis of airport-airline vertical relationships with risk sharing contracts under asymmetric information structures. Transp. Res. Part C: Emerging Technol. 44, 80-97.

[5] Murphy, Kevin M., Andrei Shleifer, and Robert W. Vishny. (1989). Industrialization and the Big Push. Journal of Political Economy, 97(5), 1003-1026.

[6] Sekeris, Theodore. (2011). Greek airports: Efficiency measurement and analysis of determinants. Journal of Air Transport Management J Air Transp Manag. 17, 139-141. 10.1016/j.jairtraman.2010.06.002.

[7] Conference Proceedings of International Conference on Management of Infrastructure (ICMI) 2017, Business Environment of Infrastructure Challenges and Way Forward ISBN: 9781-63535614-4.

[8] Retrieved from https://issuu.com/cargoconnectmagazine/docs/acaai_ final-2015.

[9] Retrieved from https://pomsmeetings.org/confproceedings/002/poms cd/browse\%20this\%20cd/papers/002-0283.pdf

[10] Retrieved from https://issuu.com/cargoconnectmagazine/docs/air_ cargo_handbook_2016_print_pdf.

[11] Retrieved from http://www.civilaviation.gov.in/sites/default/files/ Committee\%20reports\%207.pdf,accessed on 11.01.2019.

[12] Retrieved from https://www.thehindubusinessline.com/economy/ logistics/Air-cargo-business-could-soar-with-betterinfrastructure/article20258872.ece. 